\title{
MikroRNA - Molekul Versatil Dalam Kanser Tiroid
}

\author{
Azliana Mohamad Yusof ${ }^{1}$, Nurul Syakima Ab Mutalib ${ }^{2 *}$
}

${ }^{1}$ Cytogenetics and Molecular Pathology Diagnostics Laboratory, Pantai Premier Pathology Sdn Bhd, Kuala Lumpur

${ }^{2}$ UKM Medical Molecular Biology Institute, UKM Medical Center, Universiti Kebangsaan Malaysia, Cheras, Kuala Lumpur

\begin{abstract}
Abstrak : MikroRNA adalah molekul bebenang tunggal RNA kecil, dengan kepanjangan di antara 18 hingga 25 nukleotida. Molekul pengawalatur ini mampu menyasarkan lebih dari satu gen, dan dianggarkan mengawal 30\% daripada keseluruhan gen manusia. MikroRNA tidak diendahkan oleh saintis beberapa dekad sebelum ini kerana ia tidak mengekod sebarang protein lantas dianggap jujukan sampah (junk sequence), namun sejak penemuan lin-4 yang mengawalselia perkembangan larva Caenorhabditis elegans, semakin banyak kajian bertumpu ke arah molekul ini. Sebagai molekul pengawalatur (regulatory molecule), mikroRNA adalah calon kajian yang sesuai untuk penyelidikan kanser tiroid di mana landskap mutasi genomnya secara relatif lebih senyap berbanding kanser lain. Hanya sebilangan kecil gen bermutasi dikenalpasti dalam kanser tiroid dan mekanisme molekular patogenesis kanser ini masih kurang jelas. Artikel ini bertujuan untuk mendedahkan pembaca terhadap mikroRNA dan faedahnya dalam kajian kanser tiroid, serta perkembangan terkini kajian tentang mikroRNA dalam kanser ini. Penekanan terhadap peranan mikroRNA dalam kanser tiroid, dengan memfokus kepada versatiliti molekul ini dalam aplikasi diagnosis, prognosis, serta sebagai biopenanda dalam mengenalpasti pesakit yang tidak avid terhadap radioiodin akan turut dibincangkan.
\end{abstract}

Kata kunci: mikroRNA; kanser; tiroid; biopenanda

Diserahkan: $18^{\text {th }}$ May 2019

Diterima: $15^{\text {th }}$ June 2019

Diterbitkan: 05 ${ }^{\text {th }}$ July 2019

*Pengarang untuk surat-menyurat: Nurul Syakima Ab Mutalib, UKM Medical Molecular Biology Institute, UKM Medical Center, Universiti Kebangsaan Malaysia, Cheras, Kuala Lumpur; nurulsyakima@gmail.com

Citation: Mohamad Yusof et al, Ab Mutalib NS. MikroRNA - Molekul Versatil Dalam Kanser Tiroid. Prog Microbes Mol Biol 2019; 2(S1): a0000025.

\section{MIKRORNA (miRNA)}

MiRNA merupakan molekul bebenang tunggal RNA kecil bersaiz di antara 18 hingga 25 nukleotida. Ia memainkan peranan penting dalam mengawal tahap ekspresi gen dan protein berdasarkan jujukan komplimentari separa atau penuh dengan molekul sasaran RNA pengutus (messenger RNA; mRNA) (Li et al., 2010). MiRNA memodulasi ekspresi gen dengan menindas kestabilan mRNA dan/ atau merencat translasi kepada protein (Landgraf et al., 2007). Beberapa miRNA dikategorikan sebagai onkogen atau penindas tumor (Esquela-Kerscher dan Slack, 2006). Setiap miRNA mempunyai potensi untuk meregulasi lebih daripada satu mRNA sasaran dan dianggarkan 30\% daripada gen dalam badan manusia dikawal oleh miRNA (Esquela-Kerscher dan Slack, 2006).

\section{PENEMUAN MIKRORNA}

Berdekad-dekad yang lalu kewujudan miRNA tidak diendahkan dan kepentingannya diabaikan kerana ketika itu saintis hanya memfokus pada gen yang mengekod protein. Namun apabila miRNA pertama iaitu lin-4 ditemui oleh Lee dan rakan-rakan dalam Caenorhabditis elegans (C. elegans) (Lee et al., 1993), pengetahuan mengenai miRNA telah berkembang secara pesat. Pada tahun terse- but, Victor Ambros, Rosalind Lee dan Rhonda Feinbaum mendapati bahawa lin-4, iaitu gen yang mengawal masa perkembangan larva $C$. elegans tidak mengekod sebarang protein tetapi sebaliknya menghasilkan sepasang RNA kecil dengan saiz kira-kira 22 dan 61 nukleotida, di mana RNA kecil yang lebih panjang itu diramalkan untuk membentuk struktur gelung stem (stem loop) yang merupakan pelopor kepada RNA kecil yang bersaiz 22 nukleotida (Lee et al., 1993). Makmal Ambros dan Ruvkun menyedari bahawa lin-4 RNA ini mempunyai jujukan yang komplemen dengan beberapa lokasi dalam kawasan tidak diterjemah pada 3' (3' untranslated region; 3' UTR) gen lin-4 yang dihipotesiskan sebagai pengantara penindasan protein lin-14 (Lee et al., 1993; Wightman et al., 1993, 1991). Wightman dan rakan-rakan kemudiannya membuktikan kepentingan lin-4 dalam regulasi lin-14, di mana lin-4 menyebabkan penurunan ekspresi protein lin-14 tanpa perubahan mRNAnya yang nyata (Wightman et al., 1993). RNA lin-4 yang lebih pendek (22 nukleotida) itu kemudiannya dikenali sebagai pengasas sekumpulan RNA kecil yang terlibat dalam pengawalaturan gen dan dinamakan sebagai miRNA.

Tujuh tahun selepas penemuan lin-4, miRNA 
kedua iaitu let-7 telah dijumpai oleh Reinhart et al. pada tahun 2000 (Reinhart et al., 2000). Let-7 merupakan miRNA yang mengawal transisi L4 kepada tahap dewasa dalam perkembangan larva (Reinhart et al., 2000). Dalam badan manusia, let-7 telah ditemui pada peringkat ekspresi yang berbeza dalam kebanyakan tisu termasuklah jantung, otak, paru-paru, buah pinggang, kolon, usus kecil dan timus (Pasquinelli et al., 2000). Penemuan let-7 dalam pelbagai spesis mencetuskan revolusi dalam kajian miRNA. Sehingga kini, beribu-ribu miRNA telah diklasifikasikan dalam pelbagai jenis spesis termasuklah manusia. Repositori jujukan miRNA secara atas talian seperti pangkalan data miRbase telah diwujudkan dan sebanyak 24,521 lokus miRNA daripada 206 spesis di mana ia menghasilkan 38,589 miRNA matang telah direkodkan (Kozomara et al., 2019; Kozomara dan Griffiths-Jones, 2011). Sehingga kini, sebanyak 1,917 prekursor dan 2,654 miRNA matang telah diperihalkan dalam genom manusia (Kozomara et al., 2019).

\section{BIOGENESIS DAN MEKANISME MIKROR-} NA

Hampir kesemua gen miRNA ditranskripsi oleh polimerase RNA II (Pol II) dalam nukleus dengan miRNA primer (pri-miRNA) bertutup (capped), disambat (splice) dan dipoliadenilat (polyadenylated) (Lee et al., 2004). Kira-kira $30 \%$ miRNA diproses daripada intron gen mengekod protein, manakala miRNA yang lain diekspres daripada lokus gen miRNA (Lin dan Gregory, 2015). PrimiRNA boleh menghasilkan sama ada miRNA tunggal atau mengandungi dua atau lebih miRNA daripada transkrip primer yang sama. Pri-miRNA ini dibelah oleh mikropemproses yang terdiri daripada Drosha dan DGCR8 (DiGeorge syndrome critical region 8) (Gregory et al., 2004). Selepas itu, prekursor miRNA (pre-miRNA) dieksport keluar daripada nukleus ke dalam sitoplasma melalui interaksi Exportin-5 dan Ran-GTP.

Dalam sitoplasma, pre-miRNA diproses oleh DICER1, enzim RNase III yang memotong hujung 5' dan 3' pre-miRNA (Park et al., 2011). DICER1 bersamasama transactivation-responsive RNA-binding protein (TRBP) melekat pada RNA bebenang ganda dua (Bernstein et al., 2001). TRBP menghubungkan DICER1 dengan protein Argonaute (AGO1, AGO2, AGO3 atau AGO4) untuk terlibat dalam himpunan kompleks penyenyapan miRNA-teraruh (miRNA-Induced Silencing Complex; miRISC) (Chendrimada et al., 2005). Satu bebenang miRNA matang (bebenang panduan) terikat pada protein Argonaute dan dikekalkan dalam miRISC untuk memandu komplek dan famili protein GW182 kepada sasaran komplemen mRNA bagi penyenyapan gen pasca-transkripsi (Lin dan Gregory, 2015). MiRNA matang mengesan jujukan komplemen pada kawasan 3' UTR mRNA sasaran melalui jujukan benih (seed sequence) pada posisi 2 hingga 7 dalam jujukan miRNA.

\section{Perbandingan Antara miRNA Dengan RNA Bu- kan Pengekod Panjang (long noncoding RNA; IncRNA)}

RNA bukan pengekod (noncoding RNA; ncRNA) merupakan molekul RNA fungsian yang tidak ditranslasikan kepada protein. Ia dibahagikan mengikut saiz (ncRNA pendek dan ncRNA panjang), fungsi (RNA penyelenggara dan RNA pengawalaturan) dan arah transkripsi (sense/ antisense, dwiarah, intronik dan intergenik), mempunyai julat molekul yang luas dengan pelbagai fungsi dan sifat seperti mRNA, tRNA, miRNA dan lncRNA (Kunej et al., 2014). NcRNA pendek mempunyai saiz kurang daripada 200 nukleotida manakala lncRNA mempunyai saiz lebih daripada 200 nukleotida. Semenjak beberapa tahun yang lalu, banyak kajian lebih menumpukan kepada ncRNA pendek seperti miRNA, piRNA dan siRNA (Kunej et al., 2014). NcRNA yang paling banyak dikaji adalah miRNA.

Berbanding pengetahuan tentang miRNA yang lebih meluas, pemahaman mengenai lncRNA adalah masih terhad namun ianya semakin berkembang. Pelbagai mekanisma pengawalaturan transkripsi ekspresi gen oleh lncRNA telah dilaporkan. Melalui kajian-kajian ini, lncRNA dilihat membantu memodifikasi epigenetik DNA dengan merekrut komplek ubah suai kromatin kepada lokus yang spesifik (Gupta et al., 2010). LncRNA boleh diklasifikasikan kepada beberapa kelas iaitu ncRNA intergenik, ncRNA intronik, lncRNA UTR, transkrip antisense, transkrip pseudogen, ncRNA seperti-penggalak (enhancer-like ncRNA), ncRNA mitokondria, repeatassociated ncRNA dan ncRNA satelit (Gullerova, 2015). Kebanyakan fungsi lncRNA berkaitan dengan kapasiti mereka untuk mengikat pada RNA, DNA dan protein (Varilh et al., 2015). Famili lncRNA yang pertama ditemui adalah Xist (bersaiz $\sim 17$ kilobes) (Clemson et al., 1996). LncRNA berpotensi digunakan sebagai indikator aktiviti transkripsi lokus atau gen (Derrien et al., 2011). Sama seperti miRNA, lncRNA juga memainkan peranan sebagai pengaktif atau penindas ekspresi protein (Varilh et al., 2015).

\section{MIKRORNA DAN PENYAKIT MANUSIA}

Kajian terdahulu melaporkan bahawa miRNA adalah penting dalam pelbagai proses biologi dan deregulasi miRNA boleh menyebabkan pelbagai jenis penyakit dalam manusia (Li dan Kowdley, 2012). Oleh itu, pemahaman tentang bagaimana miRNA mengawalatur proses sel normal dan sesuatu penyakit adalah penting (Giza et al., 2014). Mutasi, deregulasi atau ketidakfungsian biogenesis miRNA dan sasarannya mendorong kepada kerintangan tapak jalan biokimia dan fisiologi yang terlibat dalam perkembangan dan evolusi penyakit dalam manusia. Dengan menggunakan ramalan in silico, beberapa hubungan antara miRNA dengan penyakit telah dikenalpasti (Giza et al., 2014). Perbezaan ekspresi miRNA di antara tisu normal dan tumor telah dikaji dalam pelbagai jenis kanser termasuklah kanser payudara, paru-paru, tiroid papilari, pankreas, serviks, kolon, glioblastoma dan limfoma (Giza et al., 2014). Tambahan pula, perubahan ekspresi miRNA juga dilaporkan dalam penyakit bukan kanser seperti skizofrenia, penyakit neurodegeneratif seperti Alzheimer dan Parkinson, penyakit berkaitan dengan imun serta penyakit jantung (Li dan Kowdley, 2012).

Deregulasi miRNA dalam kanser telah dilaporkan buat kali pertama pada 2002, apabila dua kluster miRNA iaitu miR-15 dan miR-16 telah dikenalpasti pada 13q14.3, kawasan delesi yang lazimnya berlaku dalam leukemia limfosit kronik (chronic lymphocytic leukemia; CLL) (Calin et al., 2002). Sejak itu, kajian mengenai per- 
anan miRNA dalam kemampuan untuk menyerang tisu persekitaran dan metastasis banyak dilaporkan (Hanahan dan Weinberg, 2011). Antara miRNA yang sering dilaporkan dalam pelbagai jenis kanser adalah miR-17-92, miR21, miR-221/222, let-7, miR-15/16, miR-200 dan miR-34 (Hayes et al., 2014). Terdapat penemuan awal yang mengatakan bahawa beberapa virus mampu mengawalatur sel perumah miRNA bagi mengawal kemandirian mereka dan virus juga boleh mengekod miRNA mereka sendiri, seperti virus polioma, adenovirus dan virus Herpes (Gregory dan Damania, 2009). Pada masa manuskrip ini ditulis, sebanyak $\sim 86,162$ penerbitan saintifik mengenai miRNA telah boleh dicapai melalui rangkaian PubMed.

\section{MIKRORNA DALAM KANSER TIROID}

Inisiasi dan progresi kanser tiroid berlaku melalui akumulasi berturutan pelbagai perubahan genetik dan epigenetik termasuklah pengaktifan dan penyahaktifan mutasi somatik, deregulasi mRNA dan/atau miRNA serta metilasi gen (Nikiforov dan Nikiforova, 2011). Berbanding kanser lain, kanser tiroid menunjukkan predisposisi genetik yang kuat seperti yang dibuktikan dalam kajian populasi kes-kawalan, di mana risiko untuk mendapat kanser ini meningkat sekurang-kurangnya lapan kali ganda di kalangan ahli keluarga yang rapat berbanding populasi umum (Risch, 2001). Namun, tiada predisposisi gen pengekod-protein dilaporkan (Swierniak et al., 2013). Maka, adalah dihipotesiskan bahawa mekanisme karsinogenesis tiroid mungkin melibatkan interaksi beberapa gen penetrasi rendah (low penetrance gene) dan gen pengawalatur seperti miRNA (Swierniak et al., 2013).

Kajian mengenai penentuan dan perbandingan profil ekspresi miRNA dalam kesemua jenis tumor tiroid, korelasi pola ekspresi miRNA dengan mutasi onkogen yang spesifik dan kelebihan diagnosis pengesanan spesifik miRNA dalam penilaian prabedah nodul tiroid telah dilakukan (Nikiforova et al., 2008). Sebanyak tujuh miRNA (miR-146b, miR-155, miR-187, miR-197, miR-221, miR-222 dan miR-224) mempunyai peningkatan ekspresi yang signifikan dalam tumor tiroid. Tambahan pula, jenis histopatologi tumor tiroid yang berbeza mempunyai profil miRNA yang berlainan, dimana ia mencerminkan mutasi bersifat onkogen yang spesifik (Nikiforova et al., 2008). Melalui kajian ini, set miRNA yang terhad mempunyai aplikasi diagnostik dengan kadar ketepatan yang tinggi bagi mengesan kanser tiroid dalam sampel pembedahan dan aspirasi jarum halus (fine-needles aspiration; FNA) prabedah (Nikiforova et al., 2008).

Meskipun pendekatan kumpulan kawalan normal dan pelantar yang digunakan adalah berbeza, namun terdapat beberapa miRNA dengan corak ekspresi yang konsisten sekurang-kurangnya daripada tiga kajian berbeza. Antara miRNA yang sering dilaporkan dalam kajian kanser tiroid papilari ialah miR-221, miR-222 dan miR146b. MiR-221 yang berekspresi tinggi sering dikaitkan dengan ciri-ciri klinikopatologi agresif dan mutasi $B R A F$ dalam kanser tiroid papilari (Zhou et al., 2012). Melalui kajian oleh Diao et al. (2016), miR-221 menindas ekspresi TIMP3 dengan mengikat pada 3'UTR TIMP3. Sebaliknya, ekspresi TIMP3 adalah tinggi dengan kehadiran perencat miR-221 (Diao et al., 2017). MiR-146a dan miR-146b tergolong dalam famili miR-146. Banyak kajian melaporkan bahawa miR-146 diekspres dengan tinggi dalam kanser tiroid papilari berbanding tisu tiroid normal (Cancer Genome Atlas Research Network, 2014; Shi et al., 2018). Melalui asai fungsian menggunakan sel selanjar kanser tiroid manusia BCPAP, miR-146b menyebabkan migrasi dan proliferasi sel kanser tiroid papilari dengan merendahkan regulasi ekspresi IRAK1. Tambahan pula, ekspresi mRNA IRAKI adalah rendah secara signifikan dalam sampel tisu kanser tiroid papilari berbanding spesimen normal bersebelahan dan hal ini menunjukkan bahawa IRAK1 mempunyai korelasi songsang yang kuat dengan miR-146b dalam kanser tiroid papilari (Chou et al., 2016).

\section{MikroRNA Sebagai Onkogen dan Penindas Tumor}

Perubahan ekspresi miRNA dalam kanser dapat menyokong hipotesis di mana miRNA memainkan peranan yang penting dalam sesuatu jenis kanser. MiRNA mempunyai profil ekspresi yang berlainan dalam kanser berbanding dengan tisu normal dan profil ini berbeza di antara pelbagai jenis kanser ( $\mathrm{Lu}$ et al., 2005) MiRNA mempunyai dua peranan dalam kanser bergantung kepada status ekspresinya. MiRNA yang diekspresi dengan tinggi dalam tumor dikenali sebagai 'onkomiR' yang lazimnya merangsang perkembangan kanser dengan merencat gen penindas tumor dan/atau gen yang mengawal proses pembezaan sel atau apoptosis (Esquela-Kerscher dan Slack, 2006). Selain itu, terdapat sesetengah miRNA diekspresi dengan rendah dalam sel kanser. MiRNA ini dikenali sebagai miRNA penindas tumor dan berfungsi menghalang perkembangan kanser dengan merencat onkogen dan/atau gen yang mengawal proses pembezaan sel atau apoptosis (Esquela-Kerscher dan Slack, 2006).

MiR-21 yang terletak pada kromosom 17 merupakan antara miRNA yang lazim dilaporkan sebagai onkomiR dalam pelbagai jenis kanser. Ekspresi miR-21 yang tinggi lazimnya dikaitkan dengan prognosis lemah di kalangan pesakit kanser. miR-21 diekspresi dengan rendah secara signifikan dalam pesakit kanser tiroid papilari berulang berbanding kanser tiroid papilari tanpa tumor berulang (Sondermann et al., 2015). Ekspresi menurun miR-21 dikaitkan dengan kanser prostat (Ren et al., 2014) tetapi miR-21 diekspresi dengan tinggi dalam kolon (Oue et al., 2014), paru-paru (M. Yang et al., 2013) dan payudara (Wang et al., 2015). Di antara sasaran miR-21 dalam kanser payudara adalah ICAM-1 (Terao et al., 2011). Dengan menggunakan kaedah transfeksi dan pengklonan, miR-21 merencat ekspresi ICAM-1, menunjukkan bahawa ia merupakan sasaran terus (direct target). Perencatan ICAM-1 secara aruhan-ATRA yang bergantung kepada miR-21 ini adalah konsisten dengan aktiviti pro-motiliti protein dalam sel kanser payudara (Strell et al., 2010). Tambahan pula, beberapa sasaran miR-21 dapat dilihat dalam pelbagai jenis kanser seperti PTEN dalam kanser kolorektal (Xiong et al., 2013) dan paru-paru (Zhang et al., 2010) serta PDCD4 dalam kanser peparu (Yang et al., 2015) dan renal (Yuan et al., 2017)

Deregulasi let-7 telah banyak dilaporkan dalam mengawalatur proliferasi dan pembezaan sel semasa 
perkembangan pelbagai spesis (Boyerinas et al., 2010). Konsisten dengan penemuan ini, ekspresi let-7 adalah rendah dalam banyak jenis kanser apabila dibandingkan dengan tisu normal dan semasa perkembangan tumor. Ekspresi rendah let-7 dilaporkan berkaitrapat dengan jangka hayat yang pendek di kalangan pesakit kanser paru-paru (Takamizawa et al., 2004). Beberapa kajian juga melaporkan bahawa aktiviti penindas tumor let-7 melingkungi pelbagai jenis kanser termasuklah gastrik (Ishiguro et al., 2014), kolon (Mizuno et al., 2018) dan ovari (Biamonte et al., 2019).

\section{MikroRNA dalam Apoptosis}

Apoptosis merupakan proses biologi kematian sel yang aktif dan kompleks di mana ia terlibat dalam penyingkiran sel yang tidak dikehendaki semasa proses perkembangan, infeksi dan homeostasis tisu (Adlakha dan Saini, 2016). Ia terjadi melalui dua tapak jalan pengisyaratan iaitu tapak jalan bersifat apoptosis intrinsik dan ekstrinsik di mana ia dicetuskan oleh molekul boleh larut yang mengikat kepada reseptor membran plasma atau pelbagai rangsangan mitokondrion (Mukhopadhyay et al., 2014). Antara miRNA yang terlibat dalam apoptosis adalah miR-181b. Dengan menggunakan sel selanjar kanser tiroid papilari TPC1, miR-181b diekspresi dengan rendah hingga menyebabkan perencatan tumbesaran sel dan menggalakkan apoptosis dengan mensasarkan CYLD (Li et al., 2014).

Gen kanser terbahagi kepada dua kumpulan kerana sel kanser selalunya dikelaskan melalui kematian sel yang rendah dan proliferasi sel yang meningkat. Kumpulan pertama iaitu onkogen meningkatkan proliferasi dan mengurangkan apoptosis. Manakala kumpulan kedua iaitu penindas tumor menjalankan fungsi yang berlawanan (Peng dan Croce, 2016). Deregulasi apoptosis merupakan satu langkah signifikan dalam kanser (Hanahan dan Weinberg, 2011). Tidak seperti sel-sel normal, sel-sel kanser adalah di bawah tekanan yang berterusan, seperti tekanan onkogenik, ketidakstabilan genomik dan hipoksia sel (Fernald dan Kurokawa, 2013). Sebagai tindak balas kepada tekanan ini, tapak jalan intrinsik apoptosis biasanya diaktifkan. Namun, sel-sel kanser mampu mengelakkan tindak balas selular ini dengan mematikan laluan apoptosis (Fernald dan Kurokawa, 2013).

Apoptosis turut dikawalselia oleh miRNA dalam perkembangan kanser tiroid seperti yang dibuktikan oleh Carvalheira et al. (2015). Melalui asai lusiferase yang menggunakan sel selanjar kanser tiroid WRO dan TPC1, miR-106b mensasarkan Clorf24 dengan mengikat pada kawasan 3'UTR. Ini menyumbang kepada pengurangan ekspresi Clorf24 yang seterusnya meningkatkan apoptosis serta merencat migrasi sel dalam kanser tiroid (Carvalheira et al., 2015). Dalam satu kajian lain, Ma et al. melaporkan bahawa peningkatan ekspresi miR-34a menggalakkan tumbesaran sel dan merencat apoptosis dengan mensasarkan GAS1 melalui tapak jalan PI3K/Akt/Bad (Ma et al., 2013).

\section{MikroRNA dalam Diagnosis dan Prognosis}

Pelbagai kajian dan analisis terhadap tahap ekspresi miRNA dalam tumorigenesis melaporkan bahawa miRNA memainkan peranan yang besar sebagai penanda prognostik dan/atau diagnostik. Ini adalah penting bagi membezakan pelbagai jenis tumor serta meramal perubahan klinikal (Kavitha et al., 2014). Perkembangan pesat teknik yang canggih seperti mikroatur, penjujukan RNA kecil, tindakbalas polimerase berantai kuantitatif (quantitative polymerase chain reaction; qPCR) dan teknologi antisense digunakan untuk memberi impak yang signifikan dalam onkologi klinikal pada masa hadapan (Rufino $\square$ Palomares et al., 2013). Sejak miRNA menjadi faktor utama dalam mengenalpasti identiti sel, miRNA juga boleh menjadi molekul yang berguna dalam diagnosis kanser. Menurut Liu et al. (2014), profil miRNA yang terekspres secara unik dan signifikan melalui analisis mikroatur miRNA dan pemprofilan miRNA berasaskan prob, mampu membezakan tisu kanser daripada tisu bukan kanser (Liu et al., 2014).

Dengan menggunakan teknik qPCR miRNA, pelbagai miRNA diekpresi dengan tinggi dan rendah dalam kanser tiroid papilari, kanser tiroid folikular, dan kanser tiroid atipikal. MiR-125b dilaporkan diekspresi dengan tinggi dalam kanser tiroid papilari apabila dibandingkan dengan tisu normal tetapi ia diekspresi dengan rendah dalam ATC (Pallante et al., 2006). Melalui kajian oleh Vriens et al. yang menggunakan pendekatan teknik qPCR, empat miRNA (miR100, miR-125b, miR-138 dan miR-768-3p) mampu membezakan sampel tisu benigna dan malignan tiroid. MiRNA ini menunjukkan potensinya sebagai penanda miRNA dalam kanser tiroid (Vriens et al., 2012). Tambahan pula, profil ekspresi miRNA juga mengandungi maklumat yang penting berkaitan dengan prognosis pesakit kanser. Sebagai contoh, ekspresi miR-21 dan miR-155 yang tinggi boleh meramal kanser berulang dan kemandirian yang tidak menggalakkan di kalangan pesakit kanser paru-paru bukan sel kecil (Yang et al., 2013) dengan mengawalatur SOCS1, SOCS6, dan PTEN (Xue et al., 2016).

\section{MikroRNA dalam Metastasis}

Kadar kematian pesakit kanser menjangkau 90\% disebabkan oleh metastasis (Budczies et al., 2014). Metastasis merupakan proses kompleks yang memerlukan sel kanser untuk terpisah daripada tumor primer dan memasuki tisu yang berdekatan melalui membran dasar (basement membrane), memasuki saluran darah (intravasatan), hidup dalam peredaran darah, keluar daripada sistem peredaran darah ke bahagian metastasis (pengektravasatan) dan masuk serta membiak pada persekitaran yang baru seterusnya membentuk tumor metastasis (kolonisasi) (Chan dan Wang, 2015). Peralihan epitelium kepada mesenkima (epithelial-mesenchymal transition; EMT) merupakan langkah penting dalam deretan metastasis, dikategorikan dengan kehilangan pelekatan sel melalui penindasan E-cadherin dan pengaktifan gen yang berkait rapat dengan invasi dan motiliti (Nisticò et al., 2012).

Melalui kajian in vitro dan in vivo, miRNA dilaporkan mempunyai peranan dalam mengawal proses metastasis. MiR-10b merupakan miRNA pertama yang dilaporkan mempunyai peranan dalam menggalakkan kanser metastasis (Ma et al., 2007). Ma dan rakan-rakan menunjukkan bahawa miR-10b menindas sintesis pro- 
tein HOXD10, lantas meninggikan ekspresi RHOC dalam kanser payudara serta meningkatkan invasi dan migrasi sel kanser. Selain itu, ekspresi miR-141 adalah rendah dalam tisu kanser tiroid dan ia berkait rapat dengan metastasis nodus limfa melalui perencatan substrat reseptor insulin (IRS2) (Dong et al., 2016). Selain itu, miR-146b-3p, miR-146b-5p dan miR-222 dilaporkan sebagai biopenanda yang berpotensi untuk mengenalpasti sentral metastasis nodus limfa dalam kanser tiroid papilari (Han et al., 2016). Wang et al juga melaporkan bahawa perubahan ekspresi yang tinggi pada miR-2861 dan miR-451 dalam kanser tiroid papilari dengan metastasis nodus limfa merupakan penanda miRNA unik yang berkaitrapat dengan prognosis dan perkembangan kanser ini (Wang et al., 2013).

\section{MikroRNA dalam Tindakbalas terhadap Terapi Radioiodin}

Kanser tiroid dirawat dengan beberapa kaedah seperti pembedahan, kemoterapi dan/atau radioterapi. Pembedahan diikuti oleh terapi radioiodin (I-131) dianggap rawatan yang optimal untuk tumor berisiko tinggi. Namun, progresi kanser tiroid sering juga dikaitkan dengan perbedaan sel kanser dan menyumbang kepada penurunan tindakbalas terhadap terapi radioiodin dalam sebilangan kecil pesakit. Pesakit yang tidak avid kepada I-131 (non-RAI avid patient) selalunya mempunyai prognosis yang buruk (Sciuto et al., 2009; Xing et al., 2013). Beberapa miRNA termasuklah miR-339-5p dan miR-195 mempunyai peranan dalam mengawalatur gen yang spesifik dalam tiroid, terutamanya simporter sodium-iodin (sodium-iodine symporter; NIS), iaitu protein utama yang terlibat dalam tindakbalas terhadap rawatan I-131 (Lakshmanan et al., 2015).

Seperti yang dinyatakan sebelum ini, miR-146b adalah antara miRNA yang paling kerap dideregulasi dalam kanser tiroid. Ekspresi miR-146b tinggi yang selalunya ditemui dalam kanser tiroid juga mungkin turut menyumbang kepada kerintangan terhadap I-131. miR-146b mampu merencat translasi NIS mRNA dan menyebabkan penurunan paras protein, kemudiannya menyebabkan pengurangan pengambilan I-131 oleh sel kanser melalui NIS (RiescoEizaguirre et al., 2015). Penemuan ini disokong oleh satu kajian fungsian lain di mana perencatan ekspresi miR-146b meningkatkan sensitiviti sel kanser terhadap I-131 (Li et al., 2015).

Kehilangan keupayaan untuk menumpukan I-131 adalah salah satu penyebab utama penyakit radioiodin-refraktori dalam kanser tiroid papilari. Untuk mengenal pasti perbezaan ekspresi miRNA dalam pesakit kanser tiroid papilari dengan metastasis paru-paru yang I-131 avid dan I-131 tidak avid, Qiu dan rakan-rakan mengkaji paras miRNA dalam serum pesakit. Berbanding kumpulan pesakit yang I-131 avid, miR-106a adalah antara miRNA yang mempunyai ekspresi tinggi yang signifikan dalam pesakit kanser tiroid papilari dengan metastasis paru-paru yang I-131 tidak avid. Analisis bioinformatik seterusnya menunjukkan bahawa miR-106a adalah miRNA teras yang mengawal selia 193 gen dalam rangkaian yang terlibat dalam keavidan terhadap I-131 (Qiu et al., 2015). Pada tahun seterusnya, kumpulan penyelidik tersebut menyiasat lebih lanjut mekanisme miR-106a dalam tindak balas terapi radioiodin. Analisis fungsian mereka menunjukkan bahawa
miRNA-106a menyasarkan retinoic acid receptor beta (RARB),mengawal ekspresi NIS dan reseptor TSH serta merubah fungsi penyerapan I-131 dalam sel kanser tiroid (Shen et al., 2016). Kajian tersebut membuka peluang kepada aplikasi perencatan miR-106a dalam pesakit kanser tiroid papilari I-131 tidak avid.

\section{RUMUSAN}

Punca kenapa kanser tiroid adalah antara kanser yang lazim berlaku di Malaysia, terutamanya di golongan wanita adalah masih kurang jelas. Kegagalan kajiankajian sebelum ini untuk mengenalpasti gen utama yang menyebabkan kanser tiroid mungkin berpunca dari interaksi di antara dua atau lebih gen yang terlibat. Oleh itu, kajian mengenai molekul pengawalatur ekspresi gen seperti miRNA, adalah lebih relevan dalam mengkaji dan memahami patogenesis kanser tiroid. Tidak dinafikan lagi, miRNA adalah molekul yang versatil dalam kanser tiroid. Peranan molekul kecil ini adalah sangat meluas, bermula dari diagnosis hinggalah kepada mempengaruhi tindakbalas terhadap rawatan. Walaupun kanser tiroid mempunyai prognosis yang baik berbanding kanser lain, masih ada sebilangan pesakit berisiko tinggi yang mempunyai prognosis buruk dan cenderung untuk mendapat kanser berulang. Kajian mendalam tentang fungsi dan peranan miRNA mampu menyumbang kearah kaedah pengesanan dan rawatan yang lebih baik untuk pesakit kanser tiroid.

\section{RUJUKAN}

Adlakha, YK, Saini, N, 2016. MicroRNA: a connecting road between apoptosis and cholesterol metabolism. Tumour Biol. J. Int. Soc. Oncodevelopmental Biol. Med. 37, 8529-8554. https://doi org/10.1007/s13277-016-4988-z

Bernstein, E. Caudy, A. A., Hammond, S.M., Hannon, G.J., 2001. Role for a bidentate ribonuclease in the initiation step of RNA interference. Nature 409, 363-366. https://doi.org/10.1038/35053110

Biamonte, F., Santamaria, G., Sacco, A., Perrone, F.M., Cello, A.D., Battaglia, A.M., Salatino, A., Vito, A.D., Aversa, I., Venturella, R., Zullo, F., Costanzo, F., 2019. MicroRNA let-7g acts as tumor suppressor and predictive biomarker for chemoresistance in human epithelial ovarian cancer. Sci. Rep. 9, 5668. https://doi.org/10.1038/s41598019-42221-X

Boyerinas, B., Park, S.-M., Hau, A., Murmann, A.E., Peter, M.E., 2010. The role of let-7 in cell differentiation and cancer. Endocr. Relat. Cancer 17, F19-36. https://doi.org/10.1677/ERC-09-0184

Budczies, J., von Winterfeld, M., Klauschen, F., Bockmayr, M., Lennerz, J.K., Denkert, C., Wolf, T., Warth, A., Dietel, M., Anagnostopoulos, I., Weichert, W., Wittschieber, D., Stenzinger, A., 2014. The landscape of metastatic progression patterns across major human cancers. Oncotarget 6, 570-583.

Calin, G.A., Dumitru, C.D., Shimizu, M., Bichi, R., Zupo, S., Noch, E., Aldler, H., Rattan, S., Keating, M., Rai, K., Rassenti, L., Kipps, T. Negrini, M., Bullrich, F., Croce, C.M., 2002. Frequent deletions and down-regulation of micro- RNA genes miR15 and miR16 at 13 q14 in chronic lymphocytic leukemia. Proc. Natl. Acad. Sci. U. S. A. 99, 15524-15529. https://doi.org/10.1073/pnas.242606799

Cancer Genome Atlas Research Network, 2014. Integrated genomic characterization of papillary thyroid carcinoma. Cell 159, 676-690. https://doi.org/10.1016/j.cell.2014.09.050

Carvalheira, G., Nozima, B.H., Cerutti, J.M., 2015. microRNA-106b-mediated down-regulation of $\mathrm{C} 1$ orf 24 expression induces apoptosis and suppresses invasion of thyroid cancer. Oncotarget 6, 28357-28370. https://doi.org/10.18632/oncotarget.4947

Chan, S.-H., Wang, L.-H., 2015. Regulation of cancer metastasis by microRNAs. J. Biomed. Sci. 22, 9. https://doi.org/10.1186/s12929 015-0113-7

Chendrimada, T.P., Gregory, R.I., Kumaraswamy, E., Norman, J., Cooch, N., Nishikura, K., Shiekhattar, R., 2005. TRBP recruits the Dicer complex to Ago2 for microRNA processing and gene silencing. Nature 436, 740-744. https://doi.org/10.1038/nature03868

Chou, C.-K., Chi, S.-Y., Huang, C.-H., Chou, F.-F., Huang, C.-C., Liu, R.- 
T., Kang, H.-Y., 2016. IRAK1, a Target of miR-146b, Reduces Cell Aggressiveness of Human Papillary Thyroid Carcinoma. J. Clin. Endocrinol. Metab. 101, 4357-4366. https://doi.org/10.1210/jc.2016-2276

Clemson, C.M., McNeil, J.A., Willard, H.F., Lawrence, J.B., 1996. XIST RNA paints the inactive $\mathrm{X}$ chromosome at interphase: evidence for a novel RNA involved in nuclear/chromosome structure. J. Cell Biol. 132, 259-275.

Derrien, T., Guigó, R., Johnson, R., 2011. The Long Non-Coding RNAs: A New (P)layer in the "Dark Matter." Front. Genet. 2, 107. https://doi. org/10.3389/fgene. 2011.00107

Diao, Y., Fu, H., Wang, Q., 2017. MiR-221 Exacerbate Cell Proliferation and Invasion by Targeting TIMP3 in Papillary Thyroid Carcinoma. Am. J. Ther. 24, e317-e328. https://doi.org/10.1097/MJT.0000000000000420

Dong, S., Meng, X., Xue, S., Yan, Z., Ren, P., Liu, J., 2016. microRNA-141 inhibits thyroid cancer cell growth and metastasis by targeting insulin receptor substrate 2. Am. J. Transl. Res. 8, 1471-1481.

Esquela-Kerscher, A., Slack, F.J., 2006. Oncomirs - microRNAs with a role in cancer. Nat. Rev. Cancer 6, 259-269. https://doi.org/10.1038/nrc1840

Fernald, K., Kurokawa, M., 2013. Evading apoptosis in cancer. Trends Cell Biol. 23, 620-633. https://doi.org/10.1016/j.tcb.2013.07.006

Giza, D.E., Vasilescu, C., Calin, G.A., 2014. Key principles of miRNA involvement in human diseases. Discov. Craiova Rom. 2, e34. https://doi. org/10.15190/d.2014.26

Gregory, R.I., Yan, K.-P., Amuthan, G., Chendrimada, T., Doratotaj, B., Cooch, N., Shiekhattar, R., 2004. The Microprocessor complex mediates the genesis of microRNAs. Nature 432, 235-240. https://doi.org/10.1038/ nature 03120

Gregory, S.M., Damania, B., 2009. KSHV and the toll of innate immune activation. Cell Cycle Georget. Tex 8, 3246-3247. https://doi.org/10.4161/ cc.8.20.9571

Gullerova, M., 2015. Long Non-coding RNA, in: Felekkis, K., Voskarides, K. (Eds.), Genomic Elements in Health, Disease and Evolution: Junk DNA. Springer New York, New York, NY, pp. 83-108. https://doi. org/10.1007/978-1-4939-3070-8 4

Gupta, R.A., Shah, N., Wang, K.C., Kim, J., Horlings, H.M., Wong, D.J., Tsai, M.-C., Hung, T., Argani, P., Rinn, J.L., Wang, Y., Brzoska, P., Kong, B., Li, R., West, R.B., van de Vijver, M.J., Sukumar, S., Chang, H.Y., 2010. Long non-coding RNA HOTAIR reprograms chromatin state to promote cancer metastasis. Nature 464, 1071-1076. https://doi. org/10.1038/nature08975

Han, P.A., Kim, H., Cho, S., Fazeli, R., Najafian, A., Khawaja, H., McAlexander, M., Dy, B., Sorensen, M., Aronova, A., Sebo, T.J., Giordano, T.J., Fahey, T.J., Thompson, G.B., Gauger, P.G., Somervell, H., Bishop, J.A., Eshleman, J.R., Schneider, E.B., Witwer, K.W., Umbricht, C.B Zeiger, M.A., 2016. Association of BRAF V600E Mutation and MicroRNA Expression with Central Lymph Node Metastases in Papillary Thyroid Cancer: A Prospective Study from Four Endocrine Surgery Centers. Thyroid Off. J. Am. Thyroid Assoc. 26, 532-542. https://doi. org/10.1089/thy.2015.0378

Hanahan, D., Weinberg, R.A., 2011. Hallmarks of cancer: the next generation. Cell 144, 646-674. https://doi.org/10.1016/j.cell.2011.02.013

Hayes, J., Peruzzi, P.P., Lawler, S., 2014. MicroRNAs in cancer: biomarkers, functions and therapy. Trends Mol. Med. 20, 460-469. https://doi. org/10.1016/j.molmed.2014.06.005

Ishiguro, H., Kimura, M., Takeyama, H., 2014. Role of microRNAs in gastric cancer. World J. Gastroenterol. WJG 20, 5694-5699. https://doi. org/10.3748/wjg.v20.i19.5694

Kavitha, N., Vijayarathna, S., Jothy, S.L., Oon, C.E., Chen, Y., Kanwar, J.R., Sasidharan, S., 2014. MicroRNAs: biogenesis, roles for carcinogenesis and as potential biomarkers for cancer diagnosis and prognosis. Asian Pac. J. Cancer Prev. APJCP 15, 7489-7497.

Kozomara, A., Birgaoanu, M., Griffiths-Jones, S., 2019. miRBase: from microRNA sequences to function. Nucleic Acids Res. 47, D155-D162. https://doi.org/10.1093/nar/gky1141

Kozomara, A., Griffiths-Jones, S., 2011. miRBase: integrating microRNA annotation and deep-sequencing data. Nucleic Acids Res. 39, D152-157. https://doi.org/10.1093/nar/gkq1027

Kunej, T., Obsteter, J., Pogacar, Z., Horvat, S., Calin, G.A., 2014. The decalog of long non-coding RNA involvement in cancer diagnosis and monitoring. Crit. Rev. Clin. Lab. Sci. 51, 344-357. https://doi.org/10.3109/10 408363.2014.944299

Lakshmanan, A., Wojcicka, A., Kotlarek, M., Zhang, X., Jazdzewski, K., Jhiang, S.M., 2015. microRNA-339-5p modulates Na+/I- symporter-mediated radioiodide uptake. Endocr. Relat. Cancer 22, 11-21. https://doi. org/10.1530/ERC-14-0439

Landgraf, P., Rusu, M., Sheridan, R., Sewer, A., Iovino, N., Aravin, A., Pfeffer, S., Rice, A., Kamphorst, A.O., Landthaler, M., Lin, C., Socci, N.D., Hermida, L., Fulci, V., Chiaretti, S., Foà, R., Schliwka, J., Fuchs, U., Novosel, A., Müller, R.-U., Schermer, B., Bissels, U., Inman, J., Phan, Q., Chien, M., Weir, D.B., Choksi, R., De Vita, G., Frezzetti, D., Trompeter, H.-I., Hornung, V., Teng, G., Hartmann, G., Palkovits, M., Di Lauro, R., Wernet, P., Macino, G., Rogler, C.E., Nagle, J.W., Ju, J., Papavasiliou, F.N., Benzing, T., Lichter, P., Tam, W., Brownstein, M.J., Bosio, A., Borkhardt, A., Russo, J.J., Sander, C., Zavolan, M., Tuschl, T., 2007. A Mammalian microRNA Expression Atlas Based on Small RNA Library Sequencing. Cell 129, 1401-1414. https://doi. org/10.1016/j.cell.2007.04.040

Lee, R.C., Feinbaum, R.L., Ambros, V., 1993. The C. elegans heterochronic gene lin-4 encodes small RNAs with antisense complementarity to lin14. Cell 75, 843-854.

Lee, Y., Kim, M., Han, J., Yeom, K.-H., Lee, S., Baek, S.H., Kim, V.N., 2004 MicroRNA genes are transcribed by RNA polymerase II. EMBO J. 23, 4051-4060. https://doi.org/10.1038/sj.emboj.7600385

Li, D., Jian, W., Wei, C., Song, H., Gu, Y., Luo, Y., Fang, L., 2014. Down-regulation of miR-181b promotes apoptosis by targeting CYLD in thyroid papillary cancer. Int. J. Clin. Exp. Pathol. 7, 7672-7680.

Li, L., Lv, B., Chen, B., Guan, M., Sun, Y., Li, H., Zhang, B., Ding, C., He, S., Zeng, Q., 2015. Inhibition of miR-146b expression increases radioiodine-sensitivity in poorly differential thyroid carcinoma via positively regulating NIS expression. Biochem. Biophys. Res. Commun. 462, 314-321. https://doi.org/10.1016/j. bbrc.2015.04.134

Li, M., Li, J., Ding, X., He, M., Cheng, S.-Y., 2010. microRNA and Cancer AAPS J. 12, 309-317. https://doi.org/10.1208/s12248-010-9194-0

Li, Y., Kowdley, K.V., 2012. MicroRNAs in common human diseases. Genomics Proteomics Bioinformatics 10, 246-253. https://doi org/10.1016/j.gpb.2012.07.005

Lin, S., Gregory, R.I., 2015. MicroRNA biogenesis pathways in cancer. Nat. Rev. Cancer 15, 321-333. https://doi.org/10.1038/nrc3932

Liu, Xin, Yan, K., Lin, X., Zhao, L., An, W., Wang, C., Liu, Xiaodong, 2014 The association between BRAF (V600E) mutation and pathological features in PTC. Eur. Arch. Oto-Rhino-Laryngol. Off. J. Eur. Fed. Oto-Rhino-Laryngol. Soc. EUFOS Affil. Ger. Soc. OtoRhino-Laryngol. - Head Neck Surg. 271, 3041-3052. https://doi org/10.1007/s00405-013-2872-7

Lu, J., Getz, G., Miska, E.A., Alvarez-Saavedra, E., Lamb, J., Peck, D., Sweet-Cordero, A., Ebert, B.L., Mak, R.H., Ferrando, A.A., Downing, J.R., Jacks, T., Horvitz, H.R., Golub, T.R., 2005. MicroRNA expression profiles classify human cancers. Nature 435, 834-838. https://doi.org/10.1038/nature03702

Ma, L., Teruya-Feldstein, J., Weinberg, R.A., 2007. Tumour invasion and metastasis initiated by microRNA-10b in breast cancer. Nature 449 , 682-688. https://doi.org/10.1038/nature06174

Ma, Y., Qin, H., Cui, Y., 2013. MiR-34a targets GAS1 to promote cell proliferation and inhibit apoptosis in papillary thyroid carcinoma via PI3K/Akt/Bad pathway. Biochem. Biophys. Res. Commun. 441, 958-963. https://doi.org/10.1016/j.bbrc.2013.11.010

Mizuno, R., Kawada, K., Sakai, Y., 2018. The Molecular Basis and Therapeutic Potential of Let-7 MicroRNAs against Colorectal Cancer. Can. J. Gastroenterol. Hepatol. 2018. https://doi. org/10.1155/2018/5769591

Mukhopadhyay, S., Panda, P.K., Sinha, N., Das, D.N., Bhutia, S.K., 2014 Autophagy and apoptosis: where do they meet? Apoptosis Int. J. Program. Cell Death 19, 555-566. https://doi.org/10.1007/s10495014-0967-2

Nikiforov, Y.E., Nikiforova, M.N., 2011. Molecular genetics and diagnosis of thyroid cancer. Nat. Rev. Endocrinol. 7, 569-580. https://doi org $/ 10.1038 /$ nrendo. 2011.142

Nikiforova, M.N., Tseng, G.C., Steward, D., Diorio, D., Nikiforov, Y.E. 2008. MicroRNA expression profiling of thyroid tumors: biological significance and diagnostic utility. J. Clin. Endocrinol. Metab. 93, 1600-1608. https://doi.org/10.1210/jc.2007-2696

Nisticò, P., Bissell, M.J., Radisky, D.C., 2012. Epithelial-Mesenchymal Transition: General Principles and Pathological Relevance with Special Emphasis on the Role of Matrix Metalloproteinases. Cold Spring Harb. Perspect. Biol. 4, a011908. https://doi.org/10.1101/ cshperspect.a011908

Oue, N., Anami, K., Schetter, A.J., Moehler, M., Okayama, H., Khan, M.A., Bowman, E.D., Mueller, A., Schad, A., Shimomura, M., Hinoi, T., Aoyagi, K., Sasaki, H., Okajima, M., Ohdan, H., Galle, P.R., Yasui, W., Harris, C.C., 2014. High miR-21 expression from FFPE tissues is associated with poor survival and response to adjuvant chemotherapy in colon cancer. Int. J. Cancer 134, 1926-1934. https://doi. org/10.1002/ijc. 28522

Pallante, P., Visone, R., Ferracin, M., Ferraro, A., Berlingieri, M.T., Troncone, G., Chiappetta, G., Liu, C.G., Santoro, M., Negrini, M., Croce, C.M., Fusco, A., 2006. MicroRNA deregulation in human thyroid papillary carcinomas. Endocr. Relat. Cancer 13, 497-508. https:// doi.org/10.1677/erc. 1.01209

Park, J.-E., Heo, I., Tian, Y., Simanshu, D.K., Chang, H., Jee, D., Patel, D.J., Kim, V.N., 2011. Dicer recognizes the 5' end of RNA for efficient and accurate processing. Nature 475, 201-205. https://doi. org/10.1038/nature 10198

Pasquinelli, A.E., Reinhart, B.J., Slack, F., Martindale, M.Q., Kuroda M.I., Maller, B., Hayward, D.C., Ball, E.E., Degnan, B., Müller, P., Spring, J., Srinivasan, A., Fishman, M., Finnerty, J., Corbo, J., Levine, M., Leahy, P., Davidson, E., Ruvkun, G., 2000. Conservation of the sequence and temporal expression of let-7 heterochronic regulatory RNA. Nature 408, 86-89. https://doi. org/10.1038/35040556

Peng, Y., Croce, C.M., 2016. The role of MicroRNAs in human cancer. Signal Transduct. Target. Ther. 1, 15004. https://doi.org/10.1038/ sigtrans. 2015.4

Qiu, Z.-L., Shen, C.-T., Song, H.-J., Wei, W.-J., Luo, Q.-Y., 2015. Differential expression profiling of circulation microRNAs in PTC patients with non-131I and 131I-avid lungs metastases: a pilot study Nucl. Med. Biol. 42, 499-504. https://doi.org/10.1016/j.nucmedbio.2015.01.009

Reinhart, B.J., Slack, F.J., Basson, M., Pasquinelli, A.E., Bettinger, J.C., Rougvie, A.E., Horvitz, H.R., Ruvkun, G., 2000. The 21-nucleotide let-7 RNA regulates developmental timing in Caenorhabditis elegans. Nature 403, 901-906. https://doi.org/10.1038/35002607

Ren, Q., Liang, J., Wei, J., Basturk, O., Wang, J., Daniels, G., Gellert, L.L., Li, Y., Shen, Y., Osman, I., Zhao, J., Melamed, J., Lee, P., 2014. Epithelial and stromal expression of miRNAs during prostate cancer progression. Am. J. Transl. Res. 6, 329-339.

Riesco-Eizaguirre, G., Wert-Lamas, L., Perales-Patón, J., Sastre-Perona, A., Fernández, L.P., Santisteban, P., 2015. The miR-146b-3p/PAX8/ NIS Regulatory Circuit Modulates the Differentiation Phenotype and Function of Thyroid Cells during Carcinogenesis. Cancer Res. 
75, 4119-4130. https://doi.org/10.1158/0008-5472.CAN-14-3547

Risch, N., 2001. The genetic epidemiology of cancer: interpreting family and twin studies and their implications for molecular genetic approaches. Cancer Epidemiol. Biomark. Prev. Publ. Am. Assoc. Cancer Res. Cosponsored Am. Soc. Prev. Oncol. 10, 733-741.

Rufino $\square$ Palomares, E.E., Reyes $\square$ Zurita, F.J., Lupiáñez, J.A., Medina, P.P 2013. MicroRNAs as Oncogenes and Tumor Suppressors, in: MicroRNAs in Medicine. John Wiley \& Sons, Ltd, pp. 223-243. https://doi. org/10.1002/9781118300312.ch14

Sciuto, R., Romano, L., Rea, S., Marandino, F., Sperduti, I., Maini, C.L., 2009. Natural history and clinical outcome of differentiated thyroid carcinoma: a retrospective analysis of 1503 patients treated at a single institution. Ann. Oncol. Off. J. Eur. Soc. Med. Oncol. 20, 1728-1735. https:// doi.org/10.1093/annonc/mdp050

Shen, C.-T., Qiu, Z.-L., Song, H.-J., Wei, W.-J., Luo, Q.-Y., 2016. miRNA-106a directly targeting RARB associates with the expression of $\mathrm{Na}+/ \mathrm{I}-\mathrm{sym}-$ porter in thyroid cancer by regulating MAPK signaling pathway. J. Exp. Clin. Cancer Res. 35, 101. https://doi.org/10.1186/s13046-016-0377-0

Shi, L., Lin, P., Wen, D., Gao, L.S., Liang, L., Luo, Y., Wei, Y., He, Y., Yang, H., Ma, W.J., 2018. Expression level of miR-146 b-5 p via miRNA sequencing and its potential targets in papillary thyroid cancer.

Sondermann, A., Andreghetto, F.M., Moulatlet, A.C.B., da Silva Victor, E., de Castro, M.G., Nunes, F.D., Brandão, L.G., Severino, P., 2015. MiR-9 and miR-21 as prognostic biomarkers for recurrence in papillary thyroid cancer. Clin. Exp. Metastasis 32, 521-530. https://doi.org/10.1007/ s10585-015-9724-3

Strell, C., Lang, K., Niggemann, B., Zaenker, K.S., Entschladen, F., 2010. Neutrophil granulocytes promote the migratory activity of MDA-MB-468 human breast carcinoma cells via ICAM-1. Exp. Cell Res. 316, 138148. https://doi.org/10.1016/j.yexcr.2009.09.003

Swierniak, M., Wojcicka, A., Czetwertynska, M., Stachlewska, E., Maciag, M., Wiechno, W., Gornicka, B., Bogdanska, M., Koperski, L., de la Chapelle, A., Jazdzewski, K., 2013. In-depth characterization of the microRNA transcriptome in normal thyroid and papillary thyroid carcinoma. J. Clin. Endocrinol. Metab. 98, E1401-1409. https://doi. org/10.1210/jc. 2013-1214

Takamizawa, J., Konishi, H., Yanagisawa, K., Tomida, S., Osada, H., Endoh, H., Harano, T., Yatabe, Y., Nagino, M., Nimura, Y., Mitsudomi, T., Takahashi, T., 2004. Reduced expression of the let-7 microRNAs in human lung cancers in association with shortened postoperative survival. Cancer Res. 64, 3753-3756. https://doi.org/10.1158/0008-5472. CAN-04-0637

Terao, M., Fratelli, M., Kurosaki, M., Zanetti, A., Guarnaccia, V., Paroni, G. Tsykin, A., Lupi, M., Gianni, M., Goodall, G.J., Garattini, E., 2011. Induction of miR-21 by retinoic acid in estrogen receptor-positive breast carcinoma cells: biological correlates and molecular targets. J. Biol. Chem. 286, 4027-4042. https://doi.org/10.1074/jbc.M110.184994

Varilh, J., Bonini, J., Taulan-Cadars, M., 2015. Role of Non-coding RNAs in Cystic Fibrosis. Cyst. Fibros. Light New Res. https://doi. org $/ 10.5772 / 60449$

Vriens, M.R., Weng, J., Suh, I., Huynh, N., Guerrero, M.A., Shen, W.T., Duh, Q.-Y., Clark, O.H., Kebebew, E., 2012. MicroRNA expression profiling is a potential diagnostic tool for thyroid cancer. Cancer 118, 34263432. https://doi.org/10.1002/cncr.26587

Wang, G., Wang, L., Sun, S., Wu, J., Wang, Q., 2015. Quantitative measurement of serum microRNA-21 expression in relation to breast cancer metastasis in Chinese females. Ann. Lab. Med. 35, 226-232. https:/ doi.org/10.3343/alm.2015.35.2.226

Wang, Z., Zhang, H., Zhang, P., Li, J., Shan, Z., Teng, W., 2013. Upregulation of miR-2861 and miR-451 expression in papillary thyroid carcinoma with lymph node metastasis. Med. Oncol. Northwood Lond. Engl. 30, 577. https://doi.org/10.1007/s12032-013-0577-9

Wightman, B., Bürglin, T.R., Gatto, J., Arasu, P., Ruvkun, G., 1991. Negative regulatory sequences in the lin-14 3'-untranslated region are necessary to generate a temporal switch during Caenorhabditis elegans development. Genes Dev. 5, 1813-1824.

Wightman, B., Ha, I., Ruvkun, G., 1993. Posttranscriptional regulation of the heterochronic gene lin-14 by lin- 4 mediates temporal pattern formation in C. elegans. Cell 75, 855-862.

Xing, M., Haugen, B.R., Schlumberger, M., 2013. Progress in molecular-based management of differentiated thyroid cancer. Lancet Lond. Engl. 381, 1058-1069. https://doi.org/10.1016/S01406736(13)60109-9

Xiong, B., Cheng, Y., Ma, L., Zhang, C., 2013. MiR-21 regulates biological behavior through the PTEN/PI-3 K/Akt signaling pathway in human colorectal cancer cells. Int. J. Oncol. 42, 219-228. https:/ doi.org/10.3892/ijo.2012.1707

Xue, X., Liu, Y., Wang, Y., Meng, M., Wang, K., Zang, X., Zhao, S., Sun, X., Cui, L., Pan, L., Liu, S., 2016. MiR-21 and MiR-155 promote non-small cell lung cancer progression by downregulating SOCS1, SOCS6, and PTEN. Oncotarget 7, 84508-84519. https://doi. org/10.18632/oncotarget.13022

Yang, M., Shen, H., Qiu, C., Ni, Y., Wang, L., Dong, W., Liao, Y., Du, J., 2013. High expression of miR-21 and miR-155 predicts recurrence and unfavourable survival in non-small cell lung cancer. Eur. J. Cancer Oxf. Engl. 1990 49, 604-615. https://doi.org/10.1016/j. ejca.2012.09.031

Yang, Y., Meng, H., Peng, Q., Yang, X., Gan, R., Zhao, L., Chen, Z., Lu, J., Meng, Q.H., 2015. Downregulation of microRNA-21 expression restrains non-small cell lung cancer cell proliferation and migration through upregulation of programmed cell death 4 . Cancer Gene Ther. 22, 23-29. https://doi.org/10.1038/cgt.2014.66

Yuan, H., Xin, S., Huang, Y., Bao, Y., Jiang, H., Zhou, L., Ren, X., Li, L., Wang, Q., Zhang, J., 2017. Downregulation of PDCD4 by miR21 suppresses tumor transformation and proliferation in a nude mouse renal cancer model. Oncol. Lett. 14, 3371-3378. https://doi. org/10.3892/ol.2017.6605

Zhang, J., Wang, J., Zhao, F., Liu, Q., Jiang, K., Yang, G., 2010. MicroRNA-21 (miR-21) represses tumor suppressor PTEN and promotes growth and invasion in non-small cell lung cancer (NSCLC) Clin. Chim. Acta Int. J. Clin. Chem. 411, 846-852. https://doi. org/10.1016/j.cca.2010.02.074

Zhou, Y.-L., Liu, C., Dai, X., Zhang, X.-H., Wang, O.-C., 2012. Overexpression of miR-221 is associated with aggressive clinicopathologic characteristics and the BRAF mutation in papillary thyroid carcinomas. Med. Oncol. Northwood Lond. Engl. 29, 3360-3366. https://doi.org/10.1007/s12032-012-0315-8

\section{GERAN}

Penulis merakamkan sekalung penghargaan kepada Kementerian Pendidikan Tinggi atas penganugerahan Skim Geran Penyelidikan Fundamental (FRGS/1/2014/ SKK01/UKM/03/1) untuk penyelidikan tentang mikroRNA dalam kanser tiroid papilari. 